\title{
On an automatic current-regulator
}

\section{Hospitalier}

To cite this article: M. Hospitalier (1879) On an automatic current-regulator, Philosophical Magazine Series 5, 7:40, 71-72, DOI: 10.1080/14786447908639559

To link to this article: http://dx.doi.org/10.1080/14786447908639559

$$
\text { 曲 Published online: } 13 \text { May } 2009 .
$$

Submit your article to this journal 전

LII Article views: 2

Q View related articles $\sqsubset$ 
decomposition of chlorate of potassium into oxygen and chloride of potassium, an exothermic reaction, and not limited by its inverse, is not arrested by a pressure of 320 atmospheres. In fact, from my measurements, the reaction

$$
\mathrm{ClO}_{6} \mathrm{~K}=\mathrm{KCl}+\mathrm{O}_{6}
$$

would liberate at the ordinary temperature $+11 \cdot 0$. At about $400^{\circ}$, the chlorate being fused and the chloride solid, the amount liberated could not but be augmented.

It is the same with the decomposition of formate by hydrate of potass, the hydrogen continuing to be liberated even under a pressure of more than 600 atmospheres. Here, again, is an exothermic reaction not limited by its inverse. In fact the transformation of the system $\mathrm{C}_{2} \mathrm{HKO}_{4}+\mathrm{KHO}_{2}$ into $\mathrm{C}_{2} \mathrm{O}_{6} \mathrm{~K}_{2}+\mathrm{H}_{2}$ would liberate at the ordinary temperature

$$
27 \% \cdot 8-259 \cdot 4=18 \cdot 4 \text { calories. }
$$

At about $400^{\circ}-500^{\circ}$, all the substances being supposed to be fused, the heat disengaged would not be much modified ; for the heats of fusion of the known salts but little exceed +4 calories, and the initial system comprises 2 fused molecules, the final system containing only 1.

Thus the exothermic reactions persist, whatever may be the amount of the pressure. It is nevertheless probable that the velocity of such a reaction is changed, and perhaps also the temperature at which it is effected; but the reaction itself does not cease to take place. This is a fresh proof in support of the opinions enunciated by the anthor of the present note, on a question so important to mechanical chemistry-opinions contested at first, but which derive fresh support from every new observation *.-Annales de Chimie et de Physique, October 1878, tome xv. p. 149.

ON AN AUTOMATIC CURRENT-REGULATOR. BY M. HOSPITALIER.

The apparatus which we have the honour to present to the Academy is composed of a resistance-coil wound in one layer only, the wire of which has been denuded along a generatrix of the spiral over a width of about 1 centimetre. A lerer, somewhat con rex, and forming a divider, is applied to the denuded part of the wire. This divider is attached at one of its extremities to an armature placed before an electro-magnet, in which the current circulates which is to be regulated. An antagonizing spring supports the lever at its other extremity. The circuit is formed by the resistance-coil, the lever, and the electromagnet. The apparatus being regulated for a determined intensity, the divider introduces into the circuit a certain number of turns of the coil. If the current increases in intensity, the electromagnet attracts its armature more strongly, the divider shifts its fulcrum and introduces into the circuit a greater number

* See Chimie organique fondée sur la Synthèse, t. ii. p. $349(1860)$; Annales de Chimie et de Physique, $3^{\mathrm{e}}$ sér. t. lxvi. pp. 41 \& 59, t. lxviii. p. 239 , and especially $4^{\mathrm{e}}$ série, t. xviii. p. 95 , and $5^{\mathrm{e}}$ série, t. xii. p. 310 , \&c. 
of turns of the coil ; the resistance increases, and the intensity is diminished. The opposite effect is produced if the intensity of the current diminishes.

By suitably regulating the force of the antagonizing spring, the electromagnet, the distribution of the wire upon the bobbin, and the curvature of the divider, we can render the system astatic; and then the apparatus gives a mathematically constant current.

In practice we can maintain the intensity of the current between two limits fixed beforehand, and as close as we will.

From an industrial point of view, the apparatus can be applied to electrotyping, to the incandescence of wires of platinum or iridium (to prevent their fusion), and, if the problem should one day receive its practical solution, to the distribution of electricity in dwelling-houses, where the apparatus will play the part of a real meter and divider of the electric current.-Comptes Rendus de l'Acalémie cles Sciences, Dec. 9, 1878, t. Ixxxvii. p. 920.

ON THE PHYSICAL STATE OF CENTRAL EUROPE IN THE TERTIARY PERIOD (AS DISPLAYED IN THE WRITINGS OF PROF. O. HEER). BY M. VAN TIEGHEM.

By publishing, in 1828, his Histoire des Végétaux fossiles, M. Ad. Brongniart laid the foundation of vegetable palæontology. Having a few years afterwards, about 1835, eutered upon the new path, M. Oswald Heer was not long in gaining therein one of the highest ranks, which he has been able to keep.

The study of the plants, and also of the insects, of the Tertiary formations bad till then been much neglected; and it was to these that Prof. Heer almost exclusively devoted the fine series of investigations which he indefatigably pursued for more than forty years.

By a great number of special memoirs, published in succession from 1836 to 1858 , he applied himself first to making known the plants and insects observed in the three horizons of the Miocene in different localities in Switzerland. Among the local floras and faunas thus established, unquestionably the richest, and also the most instructive, is that of the lignites of Eningen, belonging to the Upper Miocene, and comprising 475 species of plants. Haring accomplished this, he compared and coordinated the rich material thus acquired for science in two great works forming a whole :the Faune des Insectes tertiaires, of which I have not to speak here; and the Flore tertiaire de la Suisse, in which are described, figured, and classified 920 species of fossil plants, of which 700 were new.

A little later, completing his investigation of the Miocene plants of Switzerland, extending his researches to the vegetables of all the tertiary formations of Europe, and adding the results obtained respecting the plants of the same age found in the other regious of the globe, he endeavoured to reconstruct the world of which those creatures formed a part, and gave us his grand work entitled Recherches sur le Climat et la Végétation du Pays tertiaire, a French 